\title{
28 Quinoa, a Promising Halophyte with Modified Planting Date, and Minimum Water and Pesticide Requirements for Fars Province, Iran
}

Rezvan Talebnejad, Ali Reza Sepaskhah, and Maryam Bahrami

\section{CONTENTS}

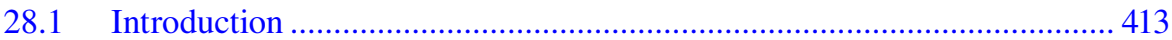

28.2 Materials and Methods ....................................................................... 415

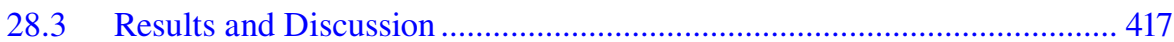

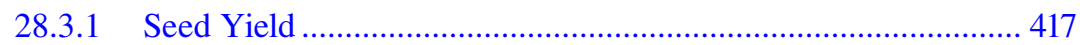

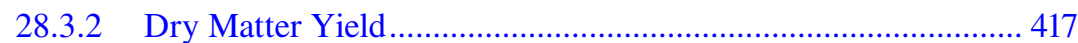

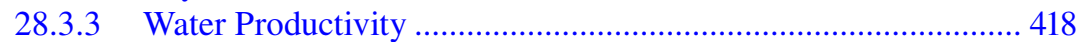

28.3.4 Physiological Parameters ......................................................................... 419

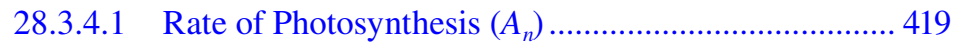

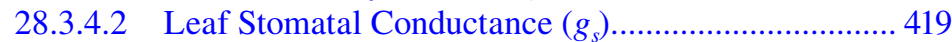

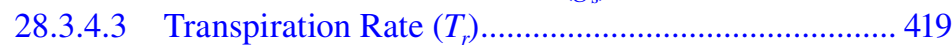

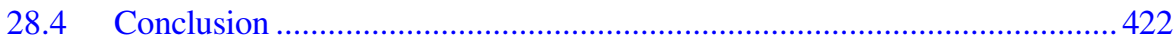

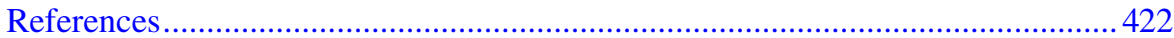

\subsection{INTRODUCTION}

Quinoa (Chenopodium quinoa Willd.) is an Andean crop domesticated in southern Peru and Bolivia close to Titicaca Lake. Quinoa is adapted to a wide range of marginal agricultural soils, including those with high salinity and those prone to drought. Recently, some research has primarily addressed salt and drought tolerance in quinoa (Jacobsen et al. 2003; Trognitz 2003; Talebnejad and Sepaskhah 2018). Its salt tolerance is the result of osmotic adjustment, sodium exclusion, and xylem loading and potassium retention (Adolf et al. 2013; Razzaghi et al. 2015). In addition, the presence of a thick plant cuticle, sunken stomata and calcium oxalate crystals in leaf 
vesicles all help to decrease leaf transpiration, increasing the tolerance of quinoa to drought stress (Jacobsen et al. 2009; Azurita-Silva et al. 2015; Issa Ali et al. 2019). Quinoa is a highly nutritious gluten-free crop, having a balanced composition of essential amino-acids sometimes scarce in legumes and cereals (Repo-Carrasco et al. 2003); it is also rich in $\mathrm{Ca}, \mathrm{Fe}$, and $\mathrm{Mg}$, and has a high content of vitamins $\mathrm{A}, \mathrm{B} 2$, and E (Ruales and Nair 1992; Adolf et al. 2013; Nowak et al. 2016). Väkeväinen et al. (2020) investigated the viability of two quinoa varieties, Pasankalla, and Rosada de Huancayo, for the development of fermented spoonable vegan products and reported that quinoa has a significant potential to be used for probiotic products. Moreover, quinoa has shown advantages for those who suffer from diabetes, dyslipidemia, obesity, or celiac disease with promising effects on health (Ceyhun et al. 2019). Romano et al. (2020) demonstrated that quinoa powders extracted from the spry-drying process are able to retain important nutritional components including lipids, antioxidants, and proteins, which suggests that a broad diversity of food products could be based on quinoa. This super grain is therefore a promising halophyte in agricultural production, which may cope with growing food demand in semi-arid areas faced with scarce water resources and soil and water salinization.

Quinoa is well adapted to grow under unfavorable soil and climatic conditions, and is rapidly gaining interest throughout the world, even in non-native regions such as Iran, because of its high nutritional value and high resistance to adverse impacts of climate change. Quinoa has different response mechanisms to endure the lack of water, including physiological strategies that operate at the levels of antioxidant defense, cell membrane stabilization, plant growth regulation, stomatal conductance, and osmotic adjustment (Hinojosa et al. 2018).

Improving water productivity (WP) in agricultural farm management can occur by increasing the economic yield of crops or decreasing the amount of irrigation water required to produce the crop. While farmers are interested in the economic output of irrigation systems, environmental policy makers are more concerned about fresh water consumption in agricultural production and other environmental impacts. The stable management of crop production requires a trade-off between economic and environmental objectives. Deficit irrigation is one of the common methods used to deal with water scarcity and limitations in available water resources: its aim is to maximize the amount of yield per unit of water consumed and is achieved by providing crops with less than the full potential evapotranspiration amount (English and Raja 1996). The full meeting of the water demands of the plant may not be an efficient management approach due to the scarcity of water resources. Acceptable yields may be possible by reducing the supply of irrigation water at different growth stages (Geerts et al. 2008). The use of deficit irrigation to achieve optimal crop yields in regions with seasonal drought has attracted the attention of many researchers (Garcia et al. 2003; Geerts et al. 2006; Kaya et al. 2015). Field experiments and modelling on quinoa yield by Geerts et al. (2009) in Bolivia showed that deficit irrigation could significantly increase the WP of quinoa for seed yield; the threshold at which dry matter production began to decrease was at approximately $55 \%$ of full irrigation. In addition, in an experiment conducted in southern Italy, Riccardi et al. (2014) found that applying irrigation water at $25 \%$ of full irrigation lead to the maximum WP of quinoa $\left(1.12 \mathrm{~kg} / \mathrm{m}^{3}\right)$. Greenhouse studies in Iran showed that quinoa grown 
with saline groundwater at $0.8 \mathrm{~m}$ depth and application of irrigation at $30 \%$ of full requirement (i.e. $70 \%$ deficit) had a decrease in seed yield of only $36 \%$ compared with that obtained in full irrigation, while there was a $12 \%$ increase in quinoa WP (Talebnejad and Sepaskhah 2015a; 2016).

Planting date is one of the most critical challenges in non-native crop cultivation. Air temperature and day length associated with different crop planting dates have been identified as critical factors in gaining economic yields on farm (Hinojosa et al. 2018). High temperature during the flowering and seed set stages can significantly decrease yields and is one of the major barriers to the global extension of quinoa cultivation (Pulvento et al. 2010; Hirich et al. 2014; Walters et al. 2016; Yang et al. 2016; Hinojosa et al. 2018). The optimum planting date for quinoa in the Ontario region (Canada) has been reported to be between May and June, while plantings in July have a 50\% decrease in yield due to the plants being still immature at first frost occurrence (Nurse et al. 2016). (These researchers have also stated that the recommended spacing of the planting rows should be greater than $75 \mathrm{~cm}$ to improve the weeding process.) In experiments in the south Mediterranean region (Egypt), researchers concluded that plant growth is higher when planting occurs at the beginning of the winter season (i.e. the last quarter of December) compared to sowing in the second quarter of December or in January. In this work, the best sowing condition was found at a relative humidity of $68.8 \%$ and with 977 hours of sunshine. Risi and Galwey (1991) analyzed the performance of two cultivars, Baer and Blanca de Junin at Cambridge, England. Their results indicated that Baer sown in March had higher yields than Blanca de Junin, implying that Baer has a higher adaptability to temperate latitudes.

Low temperature and frost during the vegetative and flowering stages of quinoa are important for effective crop management (Jacobsen et al. 2005; Rosa et al. 2009). Bois et al. (2006) surveyed the effects of various ambient temperatures on ten different quinoa cultivars; they found that temperatures below $2^{\circ} \mathrm{C}$ delayed germination, but thermal sensitivity was independent of the geographic origin of the cultivars. Freezing temperatures of $-6^{\circ} \mathrm{C}$ for nearly $4 \mathrm{~h}$ had detrimental effects on all cultivars, but $-3^{\circ} \mathrm{C}$ had no harmful influence.

In recent years, quinoa has been introduced to leading farmers in Fars province, Iran as an alternative to high water consumption crops such as rice or maize (Talebnejad and Sepaskhah 2018). Local farmers plant quinoa in spring (March and April); however, plantings at this time have a high requirement for irrigation water. A farm-level experiment was conducted at the Drought Research Center of Shiraz University, Fars province, Iran $\left(29^{\circ} 56^{\prime} \mathrm{N}, 52^{\circ} 02^{\prime} \mathrm{E}, 1810 \mathrm{~m}\right.$ above sea level) to assess the possibility of planting a Danish-bred quinoa cultivar (Titicaca, no. 5206) in September instead of the usual planting date of March. It was hypothesized that this alternative planting date would reduce crop water consumption.

\subsection{MATERIALS AND METHODS}

The experimental field was plowed at the beginning of the cultivation season, and triple superphosphate at a rate of $50 \mathrm{~kg} / \mathrm{ha}$ was mixed into the soil at plowing. Urea was applied at $250 \mathrm{~kg} / \mathrm{ha}$ at the vegetative and flowering stages of crop development. 


\section{TABLE 28.1}

\section{Mean Maximum and Minimum Monthly Temperatures during the Year of the Trial}

\begin{tabular}{lcc} 
& \multicolumn{2}{c}{ Mean Monthly Temperature ${ }^{\circ} \mathbf{C}$} \\
\cline { 2 - 3 } Month & Maximum & Minimum \\
March & 15 & 1 \\
April & 23 & 4 \\
May & 24 & 8 \\
June & 33 & 13 \\
July & 35 & 15 \\
August & 36 & 14 \\
September & 32 & 10 \\
October & 28 & 6 \\
November & 19 & -0.5 \\
\end{tabular}

The site was leveled, and 36 plots of $2 \mathrm{~m} \times 2 \mathrm{~m}$ area were established; these were bunded with ridges $\sim 30 \mathrm{~cm}$ high. Quinoa seed (Titicaca, no. 5206) was planted at $1-2 \mathrm{~cm}$ depth; each plot had 6 rows (spaced $33 \mathrm{~cm}$ apart) and the distance between each seed within rows was $15 \mathrm{~cm}$. The climatic condition of the study area was semi-arid, and the soil had a silty clay loam texture. Mean maximum and minimum daily temperatures during the two growing seasons is shown in Table 28.1.

After 2-3 weeks, the plants were thinned by hand to a stand density of $\sim 20$ plants $/ \mathrm{m}^{2}$. Plots were hand weeded every two weeks during the experiment.

The amount of water needed for irrigation was determined using the modified Penman-Monteith equation based on the daily potential evapotranspiration and crop coefficient as follows (Razzaghi and Sepaskhah 2012).

$$
E T_{o}=\frac{0.408 \Delta\left(R_{n}-G\right)+\gamma\left[\frac{900}{T+273}\right] U_{2}\left(e_{s}-e_{a}\right)}{\Delta+\gamma\left(1+0.34 U_{2}\right)}
$$

where $E T_{o}$ is the daily reference evapotranspiratyion ( $\mathrm{mm} /$ day), $T$ is the daily mean temperature $\left({ }^{\circ} \mathrm{C}\right), e_{s}$ is the mean daily saturated vapor pressure $(\mathrm{kPa}), e_{a}$ is the mean daily actual vapor pressure ( $\mathrm{kPa}), G$ is the sensible heat flux to soil $\left(\mathrm{MJ} / \mathrm{m}^{2} \mathrm{~d}\right), R_{n}$ is the daily net radiation flux $\left(\mathrm{MJ} / \mathrm{m}^{2} \mathrm{~d}\right), \gamma$ is the psychometric constant $\left(\mathrm{kPa} /{ }^{\circ} \mathrm{C}\right)$, and $\Delta$ is the slope of the saturation vapor pressure curve at the mean temperature $\left(\mathrm{kPa} /{ }^{\circ} \mathrm{C}\right)$.

Meteorological data were collected from the weather station located at the School of Agriculture, Shiraz University. Using the modified Penman-Monteith equation in combination and with the results of our previous study (Talebnejad and Sepaskhah $2015 \mathrm{~b}$ ), the crop coefficients of quinoa had been previously evaluated as $0.58,1.2$, and 0.8 , respectively for initial, mid, and final growth stages. Therefore, the crop's standard evapotranspiration was achieved by the following equation.

$$
E T_{C}=K_{c} \times E T_{o}
$$


where $E T_{c}$ is the daily standard crop evapotranspiration $(\mathrm{mm} / \mathrm{d})$, and $K_{c}$ is the crop coefficient.

The experiment had a factorial complete randomized block design with three replications. There was three irrigation treatments $(100 \%, 75 \%$, and $50 \%$ of full irrigation - FI) and two planting dates - 3 March 2018 (spring) and 1 September 2018 (autumn). Surface irrigation was applied every 7-day. The amount of water for full irrigation was $792 \mathrm{~mm}$ for the spring planting (March), and $465 \mathrm{~mm}$ for the autumn planting (September). Total rainfall was $104 \mathrm{~mm}$ for the autumn planting, while there was no rainfall for the spring planting. Harvest dates for the spring and autumn planting were 3 July and 29 November 2018, respectively.

At harvest, panicles were separated from shoots. Achenes were separated from the panicles, and their covers were robed from the seeds. The seeds were dried in the open air for 48-72 h to determine seed yield. Plant shoots were dried in an oven at $65^{\circ} \mathrm{C}$ for $48-72 \mathrm{~h}$ to determine shoot dry matter. The WP of the seed yield was calculated by dividing the seed yield by amount of irrigation water applied. Also, the WP of the total dry matter (TDM) was calculated by dividing the TDM by the mount of applied irrigation water.

Leaf gas exchange parameters were measured with an LCi analyzer (Li-Cor Inc, Nebraska, USA) at 13:00 pm before irrigation at bud formation. Measured parameters included the net rates of photosynthesis and transpiration $\left(A_{n}\right.$ and $\left.T_{r}\right)$, stomatal conductance $\left(g_{s}\right)$. The ratio $A_{n} / g_{s}$ was also calculated as an index of intrinsic water use efficiency (IWUE).

The effects of deficit irrigation and planting date on quinoa yield were evaluated using analysis of variance, and the means were compared using Duncan's multiple range test. All data were normally distributed so no transformation of data was required.

\subsection{RESULTS AND DISCUSSION}

\subsubsection{SeED YieLD}

Table 28.2 compares the effects the two planting dates, three irrigation regimes on seed yield, TDM, WP of the seed yield, and WP of the TDM. The average yield of quinoa seed was $4.6 \mathrm{Mg} / \mathrm{ha}$ for the spring (March) planting, but this increased by $10 \%$ to $5.06 \mathrm{Mg} / \mathrm{ha}$ for the autumn (September) planting. There was, no significant difference in yield between the FI and $0.75 \mathrm{FI}$ irrigation regimes, but the yields with 0.50 FI were significantly lower with both the spring and autumn plantings. Deficit irrigation ( $50 \% \mathrm{FI})$ decreased the seed yield by $17 \%$ in spring and by $14 \%$ in autumn. The lowest yield was $3.8 \mathrm{Mg} / \mathrm{ha}$ for the spring planting with $0.50 \mathrm{FI}$. Our findings show that with higher rainfall and lower evapotranspiration, the autumn planting of quinoa used less irrigation water with no significant drop in seed yield compared with that obtained in the spring planting.

\subsubsection{Dry Matter Yield}

TDM was higher for the crop planted in autumn than for the crop planted in spring (Table 28.2). The highest TDM (13.6 Mg/ha) was for the autumn planting date with 
TABLE 28.2

Seed Yield (SY), Total Dry Matter (TDM), WP of

Seed Yield $\left(W_{P_{S Y}}\right)$, and WP of Total Dry Matter

$\left(\mathbf{W P}_{\mathrm{TDM}}\right)$ with the Different Planting Date and

Irrigation Regimes

\begin{tabular}{|c|c|c|}
\hline \multirow[b]{2}{*}{ Irrigation Regime } & \\
\hline & Spring & Autumn \\
\hline \multicolumn{3}{|l|}{ SY (Mg/ha) } \\
\hline FI & $4.60 \mathrm{ab}^{*}$ & $5.06 \mathrm{a}$ \\
\hline $0.75 \mathrm{FI}$ & $4.46 \mathrm{ab}$ & $4.67 \mathrm{a}$ \\
\hline $0.50 \mathrm{FI}$ & $3.80 \mathrm{c}$ & $4.36 \mathrm{ab}$ \\
\hline \multicolumn{3}{|l|}{ TDM (Mg/ha) } \\
\hline FI & $10.25 \mathrm{c}$ & $13.6 \mathrm{a}$ \\
\hline $0.75 \mathrm{FI}$ & $9.02 \mathrm{~cd}$ & $12.02 \mathrm{~b}$ \\
\hline $0.50 \mathrm{FI}$ & $8.35 \mathrm{~d}$ & $10.42 \mathrm{c}$ \\
\hline \multicolumn{3}{|l|}{$\mathrm{WP}_{\mathrm{SY}}\left(\mathrm{kg} / \mathrm{m}^{3}\right)$} \\
\hline FI & $0.64 \mathrm{~d}$ & $1.09 \mathrm{c}$ \\
\hline $0.75 \mathrm{FI}$ & $0.74 \mathrm{~d}$ & $1.48 \mathrm{~b}$ \\
\hline $0.50 \mathrm{FI}$ & $0.81 \mathrm{~d}$ & $2.78 \mathrm{a}$ \\
\hline \multicolumn{3}{|l|}{$\mathrm{WP}_{\mathrm{TDM}}\left(\mathrm{kg} / \mathrm{m}^{3}\right)$} \\
\hline FI & $1.43 \mathrm{~d}$ & $2.93 \mathrm{c}$ \\
\hline $0.75 \mathrm{FI}$ & $1.51 \mathrm{~d}$ & $3.82 \mathrm{~b}$ \\
\hline $0.50 \mathrm{FI}$ & $1.72 \mathrm{~d}$ & $6.64 \mathrm{a}$ \\
\hline
\end{tabular}

full irrigation, while the lowest TDM $(8.35 \mathrm{Mg} / \mathrm{ha})$ was for the spring planting with 0.50 FI. Results also revealed that the difference between the values in the autumn season is higher than those obtained in the spring planting. Decreasing irrigation water from full irrigation to $50 \%$ FI caused a $23 \%$ decrease in TDM for the autumn planting, and an $18 \%$ decrease in TDM for the spring planting.

\subsubsection{Water Productivity}

In the case of WP of seed yield, the most water efficient value was with the autumn planting and the $0.50 \mathrm{FI}$ regime $\left(2.78 \mathrm{~kg} / \mathrm{m}^{3}\right.$ (Table 28.2), and the least efficient value was $0.64 \mathrm{~kg} / \mathrm{m}^{3}$ with the spring planting with FI. Data analysis revealed that with the autumn planting, increasing the water stress to mild (0.75FI) and high levels $(0.50 \mathrm{FI})$ significantly increased WP by $35 \%$ and $155 \%$, respectively. By contrast, with the spring planting, the implementation of the mild and high water stress increased $\mathrm{WP}_{\mathrm{SY}}$ by $16 \%$ and $26 \%$, respectively, although these increases were not significantly different to the FI controls. 
The WP of the TDM was also significantly affected by the different irrigation treatments with the autumn planting. Decreasing the irrigation to $75 \%$ and $50 \%$ of FI caused $30 \%$ and $127 \%$ increases in $\mathrm{WP}_{\mathrm{TDM}}$, respectively. By contrast, with the quinoa planted in spring there was no significant effect of decreasing irrigation on $\mathrm{WP}_{\mathrm{TDM}}$. The highest $\mathrm{WP}_{\mathrm{TDM}}$ was $6.64 \mathrm{~kg} / \mathrm{m}^{3}$ for the autumn planting with $0.50 \mathrm{FI}$; the lowest value was $1.43 \mathrm{~kg} / \mathrm{m}^{3}$ for the spring planting and full irrigation. Similar results were reported by Razzaghi et al. (2012).

In general, the deficit irrigation strategy increased $\mathrm{WP}_{\text {seed }}$ due to the use of less irrigation water. However, water stress in spring was more detrimental to seed yield as it decreased stomata conductance and restricted plant photosynthesis. Obviously, such a yield decrease is not desirable for farmers as it restricts their economic benefits. Therefore, quinoa autumn planting is recommended in order to secure farmers benefits. Improved varieties and plant breeding to develop water stress tolerant variety of quinoa would be a solution for this conflict.

\subsubsection{Physiological Parameters}

Table 28.3 summarizes the effects of the different planting dates and various irrigation regimes on the leaf gas exchange characteristics of quinoa.

\subsubsection{Rate of Photosynthesis $\left(A_{n}\right)$}

Averaged across all irrigation treatments, rates of photosynthesis were $\sim 30 \%$ higher with the autumn planting than with the spring planting. Decreasing the application of irrigation water significantly decreased $A_{n}$ for both spring and autumn plantings. These effects were greatest with the 0.50 FI treatment, which decreased $A_{n}$ by $25 \%$ with the spring planting and by $17 \%$ with the autumn planting. The highest rate of photosynthesis $\left(14.68 \mu \mathrm{mol} / \mathrm{m}^{2} / \mathrm{s}\right)$ occurred in the autumn planting with full irrigation. The lowest rate of photosynthesis $\left(9.08 \mu \mathrm{mol} / \mathrm{m}^{2} / \mathrm{s}\right)$ occurred in the spring planting with $0.50 \mathrm{FI}$. The highest value of $A_{n}$ was therefore $\sim 60 \%$ greater than the lowest value.

\subsubsection{Leaf Stomatal Conductance $\left(g_{s}\right)$}

The changes in the photosynthetic rate caused by water stress were primarily due to stomatal closure. Averaged across all irrigation treatments $g_{s}$ was $\sim 35 \%$ higher for quinoa planted in autumn compared with the spring. Deficit irrigation decreased $g_{s}$ with adverse effects being greatest at $50 \% \mathrm{FI}$; this decreased $g_{s}$ by $62 \%$ with the spring planting and by $47 \%$ with the autumn planting. The highest $g_{s}$ was $0.32 \mathrm{~mol} /$ $\mathrm{m}^{2} / \mathrm{s}$ with the autumn planted full irrigation treatment and the lowest $g_{\mathrm{s}}$ was $0.10 \mathrm{~mol} / \mathrm{m}^{2} / \mathrm{s}$ with the spring planted $0.50 \mathrm{FI}$ treatment. In general, $g_{s}$ was more sensitive to water stress than $A_{n}$. The highest value of $g_{s}$ was $\sim 220 \%$ greater than the lowest value. Similar results were reported by Talebnejad and Sepaskhah (2016).

\subsubsection{Transpiration Rate $\left(T_{r}\right)$}

In general, $T_{r}$ was $\sim 9 \%$ higher with the spring than the autumn planting; this was likely to have occurred because of higher air temperature and lower relative humidity in spring than in autumn. Generally, transpiration has been shown to decrease in quinoa in arid and semi-arid climates under high water stress (Hinojosa et al. 2018). 


\begin{tabular}{|c|c|c|}
\hline \multicolumn{3}{|l|}{ TABLE 28.3} \\
\hline \multirow{2}{*}{\multicolumn{3}{|c|}{$\begin{array}{l}\text { Photosynthesis Rate }\left(A_{n}\right) \text {, Stomatal Conductance } \\
\left(g_{s}\right) \text {, Transpiration Rate }\left(T_{r}\right) \text {, Intrinsic Water Use } \\
\text { Efficiency }\left(A_{n} / g_{s}\right) \text {, and Transpiration Efficiency } \\
\left(A_{n} / T_{r}\right) \text { at Different Planting Date and Irrigation } \\
\text { Regimes }\end{array}$}} \\
\hline & & \\
\hline \multirow[t]{2}{*}{ Irrigation Regime } & \multicolumn{2}{|c|}{ Planting Date } \\
\hline & Spring & Autumn \\
\hline \multicolumn{3}{|l|}{$A_{n}\left(\mu \mathrm{mol} / \mathrm{m}^{2} / \mathrm{s}\right)$} \\
\hline FI & $12.05 b^{*}$ & $14.68 \mathrm{a}$ \\
\hline $0.75 \mathrm{FI}$ & $9.91 \mathrm{c}$ & $13.20 \mathrm{ab}$ \\
\hline $0.50 \mathrm{FI}$ & $9.08 \mathrm{c}$ & $12.20 \mathrm{~b}$ \\
\hline \multicolumn{3}{|l|}{$g_{s}\left(\mathrm{~mol} / \mathrm{m}^{2} / \mathbf{s}\right)$} \\
\hline FI & $0.26 \mathrm{~b}$ & $0.32 \mathrm{a}$ \\
\hline $0.75 \mathrm{FI}$ & $0.18 \mathrm{~cd}$ & $0.24 \mathrm{bc}$ \\
\hline $0.50 \mathrm{FI}$ & $0.10 \mathrm{e}$ & $0.17 \mathrm{~d}$ \\
\hline \multicolumn{3}{|l|}{$T_{r}\left(\mathrm{mmol} / \mathrm{m}^{2} / \mathrm{s}\right)$} \\
\hline FI & $4.27 \mathrm{a}$ & $4.10 \mathrm{ab}$ \\
\hline $0.75 \mathrm{FI}$ & $3.87 \mathrm{~b}$ & $3.43 \mathrm{c}$ \\
\hline $0.50 \mathrm{FI}$ & $3.12 \mathrm{~cd}$ & $2.78 \mathrm{~d}$ \\
\hline \multicolumn{3}{|l|}{$A_{n} / g_{s}(\mu \mathrm{mol} / \mathrm{mol})$} \\
\hline FI & $47.24 \mathrm{c}$ & $46.09 \mathrm{c}$ \\
\hline $0.75 \mathrm{FI}$ & $55.06 \mathrm{c}$ & $56.52 \mathrm{c}$ \\
\hline $0.50 \mathrm{FI}$ & $91.31 \mathrm{a}$ & $70.88 \mathrm{~b}$ \\
\hline \multicolumn{3}{|l|}{$A_{n} / T_{r}(\mathrm{~g} / \mathbf{k g})$} \\
\hline FI & $2.83 \mathrm{c}$ & $3.57 \mathrm{~b}$ \\
\hline $0.75 \mathrm{FI}$ & $2.50 \mathrm{c}$ & $3.84 \mathrm{~b}$ \\
\hline $0.50 \mathrm{FI}$ & $2.92 \mathrm{c}$ & $4.41 \mathrm{a}$ \\
\hline
\end{tabular}

Our data were consistent with this view. With the 0.75 FI treatment, $T_{r}$ was $9 \%$ lower in spring and $16 \%$ lower in autumn than with the equivalent full irrigation treatment. With the 50 FI treatment, the adverse effects were even stronger: $T_{r}$ was $27 \%$ lower in spring and $32 \%$ lower in autumn than with the equivalent full irrigation treatment. The highest rate was $4.27 \mathrm{mmol} / \mathrm{m}^{2} / \mathrm{s}$ for the quinoa which planted in spring and treated with full irrigation. The lowest rate was $2.78 \mathrm{mmol} / \mathrm{m}^{2} / \mathrm{s}$ for the autumn planting and the $0.50 \mathrm{FI}$ treatment.

Other factors calculated in Table 28.3 were the IWUE (evaluated as the ratio $A_{n} / g_{s}$; c.f. Rawson et al. 1977) and the transpiration efficiency (TE; defined as $A_{n} / T_{r}$ ). A decrease in irrigation from FI to 0.75 FI, had no significant effect on IWUE, however, decreasing irrigation from FI to 0.50 FI significantly increased IWUE with both the spring and autumn planting. The highest rise (93\%) occurred with a $50 \%$ reduction in 


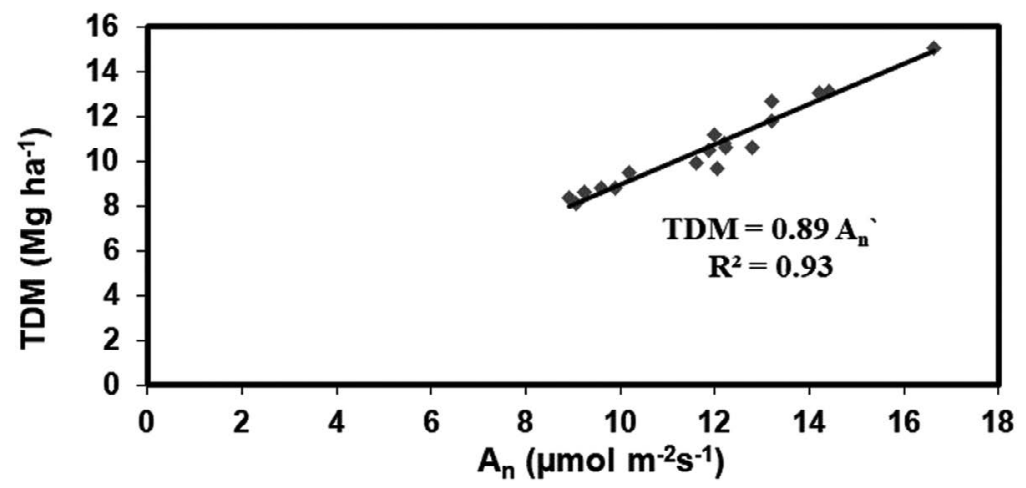

FIGURE 28.1 Relationship between total dry matter (TDM) and net photosynthetic rate $\left(A_{n}\right)$.

irrigation in spring; by contrast, with the autumn planting scenario a $50 \%$ reduction in irrigation improved the IWUE by $54 \%$. The transpiration efficiency was less sensitive than the IWUE to different water deficits, especially when the seeds were planted in spring. With the spring planting, there was no significant difference between any irrigation treatment; the value averaged across irrigation treatments was $2.75 \mathrm{~g} / \mathrm{kg}$. However, when the seeds were planted in autumn, the transpiration efficiency was higher than that obtained with the spring planting, and deficit irrigation increased the TE; the highest TE $(4.41 \mathrm{~g} / \mathrm{kg})$ was with the irrigation $0.50 \mathrm{FI}$ treatment.

Across all treatments, we also examined the relationships between growth and the physiological parameters measured. Figure 28.1 shows that there was a positive linear relationship between the TDM and the rate of photosynthesis $\left(A_{n}\right)$. This behavior is in agreement with the similar results observed in wheat (Sikder et al. 2015), cotton (Brugnoli and Lauteri 1991) and saffron (Yarami and Sepaskhah 2015; Dastranj and Sepaskhah 2019).

Figure 28.2 shows that there was a positive linear relationship between $A_{n}$ and $g_{s}$, which shows that water stress impacted on photosynthesis less than stomatal

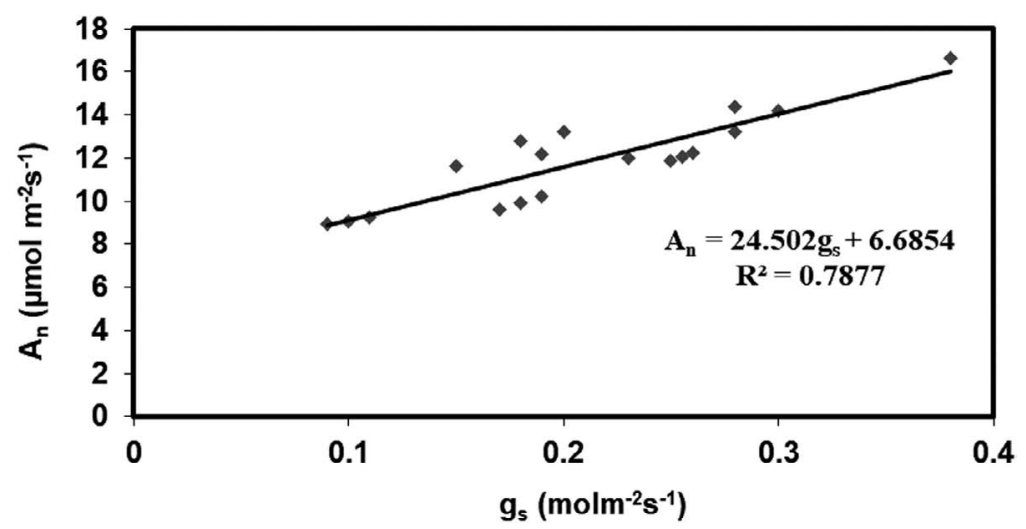

FIGURE 28.2 Relationship between net photosynthetic rate $\left(A_{n}\right)$ and stomatal conductance $\left(g_{s}\right)$. 


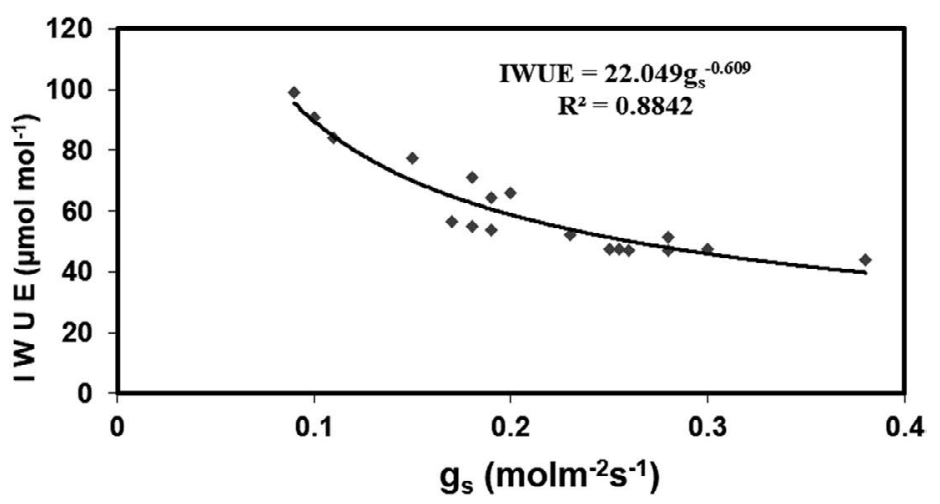

FIGURE 28.3 Relationship between intrinsic water use efficiency (IWUE) and stomatal conductance $\left(g_{s}\right)$.

conductance and consequently decreased dry matter accumulation. This is in accordance with dry matter reduction under deficit irrigation treatments.

Figure 28.3 shows that there was a negative curvilinear relationship between intrinsic water use efficiency (IWUE) and stomatal conductance $\left(g_{s}\right)$. This is consistent with similar trends reported in the literature (Razzaghi et al. 2015; Talebnejad and Sepaskhah 2016b; Mehrabi and Sepaskhah 2019); however, the data also suggest that an increase in IWUE through a reduction in $\mathrm{g}_{\mathrm{s}}$ is more sensitive (higher slope in trendline equation) in semi-arid conditions as compared with that obtained in humid weather conditions as reported by Razzaghi et al. (2015).

\subsection{CONCLUSION}

The average quinoa seed yield was $4.6 \mathrm{Mg} / \mathrm{ha}$ for spring planting in March while it increased to $5.06 \mathrm{Mg} / \mathrm{ha}$ in autumn planting in September. Our results have shown that quinoa planted in autumn can complete its growth cycle, with significantly less irrigation water, and with no pesticide application, compared with quinoa planted in spring. The autumn (September) planting required $40 \%$ less irrigation water and had a $10 \%$ higher yield compared with the planting in spring (March) planting. The quinoa planted in early autumn flowered well, had a good seed set and avoided pest damage; by contrast, the spring planting required a pesticide application to control the pests that were promoted by the high temperatures occurring in June. It is therefore recommended that quinoa be planted in autumn in Fars Province, Iran. It is important to note that our research was conducted in an area with an arid climate with an average ratio of annual precipitation to average annual evaporation ratio $(\mathrm{P} / \mathrm{E})$ of 0.15 . The results of our research may be generalized to similar climates for quinoa cultivation.

\section{REFERENCES}

Adolf, V.I., S.-E. Jacobsen, and S. Shabala. 2013. "Salt Tolerance Mechanisms in Quinoa (Chenopodium Quinoa Willd.)." Environmental and Experimental Botany 92: 43-54. https://doi.org/10.1016/j.envexpbot.2012.07.004. 
Azurita-Silva, A., S.E. Jacobsen, F. Razzaghi, R. Alvarez Flores, K. Ruiz, A. Morales, and S. Herman. 2015. "Quinoa Drought Responses and Adaptation." In In State of the Art Report of Quinoa in the World in 2013, 157-171. Rome: FAO and CIRAD.

Bois, J.F., T. Winkel, J.P. Lhomme, J.P. Raffaillac, and A. Rocheteau. 2006. "Response of Some Andean Cultivars of Quinoa (Chenopodium Quinoa Willd.) to Temperature: Effects on Germination, Phenology, Growth and Freezing." European Journal of Agronomy 25 (4): 299-308. https://doi.org/10.1016/j.eja.2006.06.007.

Brugnoli, E. and M. Lauteri. 1991. "Effects of Salinity on Stomatal Conductance, Photosynthetic Capacity, and Carbon Isotope Discrimination of Salt-Tolerant (Gossypium Hirsutum L.) and Salt-Sensitive (Phaseolus Vulgaris L.) C3 NonHalophytes.” Plant Physiology 95 (2): 628 LP-635. https://doi.org/10.1104/pp.95.2.628.

Ceyhun S., Aybuke and N. Sanlier. 2019. "A New Generation Plant for the Conventional Cuisine: Quinoa (Chenopodium Quinoa Willd.).” Trends in Food Science \& Technology 86: 51-58. https://doi.org/10.1016/j.tifs.2019.02.039.

Dastranj, M. and A.R. Sepaskhah. 2019. "Response of Saffron (Crocus Sativus L.) to Irrigation Water Salinity, Irrigation Regime and Planting Method: Physiological Growth and Gas Exchange." Scientia Horticulturae 257: 108714. https://doi.org/10.1016/j. scienta.2019.108714.

English, M. and S.N. Raja. 1996. "Perspectives on Deficit Irrigation.” Agricultural Water Management 32 (1): 1-14. https://doi.org/10.1016/S0378-3774(96)01255-3.

Garcia, M., D. Raes, and S.E. Jacobsen. 2003. "Evapotranspiration Analysis and Irrigation Requirements of Quinoa (Chenopodium Quinoa) in the Bolivian Highlands." Agricultural Water Management 60 (2): 119-134. https://doi.org/10.1016/ S0378-3774(02)00162-2.

Geerts, S., D. Raes, M. Garcia, C. Taboada, R. Miranda, J. Cusicanqui, T. Mhizha, and J. Vacher. 2009. "Modeling the Potential for Closing Quinoa Yield Gaps under Varying Water Availability in the Bolivian Altiplano." Agricultural Water Management 96 (11): 1652-1658. https://doi.org/10.1016/j.agwat.2009.06.020.

Geerts, S., D. Raes, M. Garcia, C. Del Castillo, and W. Buytaert. 2006. "Agro-Climatic Suitability Mapping for Crop Production in the Bolivian Altiplano: A Case Study for Quinoa." Agricultural and Forest Meteorology 139 (3-4): 399-412. https://doi. org/10.1016/j.agrformet.2006.08.018.

Geerts, S., D. Raes, M. Garcia, O. Condori, J. Mamani, R. Miranda, J. Cusicanqui, C. Taboada, E. Yucra, and J. Vacher. 2008. "Could Deficit Irrigation Be a Sustainable Practice for Quinoa (Chenopodium Quinoa Willd.) in the Southern Bolivian Altiplano?" Agricultural Water Management 95 (8): 909-917. https://doi.org/10.1016/j. agwat.2008.02.012.

Hinojosa, L., J.A. González, F.H. Barrios-Masias, F. Fuentes, and K.M. Murphy. 2018. "Quinoa Abiotic Stress Responses: A Review." Plants. https://doi.org/10.3390/ plants7040106.

Hirich, A., R. Choukr-Allah, and S.-E. Jacobsen. 2014. "Quinoa in Morocco - Effect of Sowing Dates on Development and Yield." Journal of Agronomy and Crop Science 200 (5): 371-77. https://doi.org/10.1111/jac.12071.

Issa A., O. R. Fghire, F. Anaya, O. Benlhabib, and S. Wahbi. 2019. "Physiological and Morphological Responses of Two Quinoa Cultivars (Chenopodium Quinoa Willd.) to Drought Stress." Gesunde Pflanzen 71 (2): 123-33. https://doi.org/10.1007/ s10343-019-00460-y.

Jacobsen, S.-E., A Mujica, and C.R. Jensen. 2003. "The Resistance of Quinoa (Chenopodium QuinoaWilld.) to Adverse Abiotic Factors.” Food Reviews International 19 (1-2): 99-109. https://doi.org/10.1081/FRI-120018872.

Jacobsen, S.E., C. Monteros, J.L. Christiansen, L.A. Bravo, L.J. Corcuera, and A. Mujica. 2005. "Plant Responses of Quinoa (Chenopodium Quinoa Willd.) to Frost at Various 
Phenological Stages." European Journal of Agronomy 22 (2): 131-139. https://doi. org/10.1016/j.eja.2004.01.003.

Jacobsen, S.-E., F. Liu, and C.R. Jensen. 2009. "Does Root-Sourced ABA Play a Role for Regulation of Stomata under Drought in Quinoa (Chenopodium Quinoa Willd.)." Scientia Horticulturae 122 (2): 281-287. https://doi.org/10.1016/j.scienta.2009.05.019.

Kaya, Ç.I., A. Yazar, and S.M. Sezen. 2015. "SALTMED Model Performance on Simulation of Soil Moisture and Crop Yield for Quinoa Irrigated Using Different Irrigation Systems, Irrigation Strategies and Water Qualities in Turkey." Agriculture and Agricultural Science Procedia 4: 108-118. https://doi.org/10.1016/j.aaspro.2015.03.013.

Mehrabi, F. and A.R. Sepaskhah. 2019. "Partial Root Zone Drying Irrigation, Planting Methods and Nitrogen Fertilization Influence on Physiologic and Agronomic Parameters of Winter Wheat." Agricultural Water Management 223: 105688. https:// doi.org/10.1016/j.agwat.2019.105688.

Nowak, V., J. Du, and U.R. Charrondière. 2016. "Assessment of the Nutritional Composition of Quinoa (Chenopodium Quinoa Willd.)." Food Chemistry 193: 47-54. https://doi. org/10.1016/j.foodchem.2015.02.111.

Nurse, R.E., K. Obeid, and E.R. Page. 2016. "Optimal Planting Date, Row Width, and Critical Weed-Free Period for Grain Amaranth and Quinoa Grown in Ontario, Canada." Canadian Journal of Plant Science 96 (3): 360-366. https://doi.org/10.1139/ cjps-2015-0160.

Pulvento, C., M. Riccardi, A. Lavini, R. D’Andria, G. Iafelice, and E. Marconi. 2010. "Field Trial Evaluation of Two Chenopodium Quinoa Genotypes Grown Under Rain-Fed Conditions in a Typical Mediterranean Environment in South Italy." Journal of Agronomy and Crop Science 196 (6): 407-411. https://doi.org/10.1111/j.1439-037X.2010.00431.x.

Rawson, H.M., J.E. Begg, and R.G. Woodward. 1977. "The Effect of Atmospheric Humidity on Photosynthesis, Transpiration and Water Use Efficiency of Leaves of Several Plant Species." Planta 134 (1): 5-10. https://doi.org/10.1007/BF00390086.

Razzaghi, F., S.-E. Jacobsen, C.R. Jensen, and M.N. Andersen. 2015. "Ionic and Photosynthetic Homeostasis in Quinoa Challenged by Salinity and Drought - Mechanisms of Tolerance." Functional Plant Biology 42 (2): 136-148.

Razzaghi, F., F. Plauborg, S.E. Jacobsen, C.R. Jensen, and M.N. Andersen. 2012. "Effect of Nitrogen and Water Availability of Three Soil Types on Yield, Radiation Use Efficiency and Evapotranspiration in Field-Grown Quinoa." Agricultural Water Management 109: 20-29. https://doi.org/10.1016/j.agwat.2012.02.002.

Razzaghi, F. and A. R. Sepaskhah. 2012. "Calibration and Validation of Four Common ET0 Estimation Equations by Lysimeter Data in a Semi-Arid Environment." Archives of Agronomy and Soil Science 58 (3): 303-319. https://doi.org/10.1080/03650340.2010.518957.

Repo-Carrasco, R., C. Espinoza, and S.-E. Jacobsen. 2003. "Nutritional Value and Use of the Andean Crops Quinoa (Chenopodium Quinoa) and Kaniva (Chenopodium Pallidicaule)." Food Reviews International 19 (1-2): 179-189. https://doi.org/10.1081/ FRI-120018884.

Riccardi, M., C. Pulvento, A. Lavini, R. d'Andria, and S. E. Jacobsen. 2014. "Growth and Ionic Content of Quinoa under Saline Irrigation." Journal of Agronomy and Crop Science 200 (4): 246-260. https://doi.org/10.1111/jac.12061.

Risi, J. and N.W. Galwey. 1991. "Effects of Sowing Date and Sowing Rate on Plant Development and Grain Yield of Quinoa (Chenopodium Quinoa) in a Temperate Environment." The Journal of Agricultural Science 117 (3): 325-332. https://doi.org/ DOI: $10.1017 / \mathrm{S} 002185960006706 \mathrm{X}$.

Romano, N., M. Micaela Ureta, M. Guerrero-Sánchez, and A. Gómez-Zavaglia. 2020. "Nutritional and Technological Properties of a Quinoa (Chenopodium Quinoa Willd.) Spray-Dried Powdered Extract.” Food Research International 129: 108884. https://doi. org/10.1016/j.foodres.2019.108884. 
Rosa, M., M. Hilal, J.A. González, and F.E. Prado. 2009. “Low-Temperature Effect on Enzyme Activities Involved in Sucrose-Starch Partitioning in Salt-Stressed and Salt-Acclimated Cotyledons of Quinoa (Chenopodium Quinoa Willd.) Seedlings." Plant Physiology and Biochemistry 47 (4): 300-307. https://doi.org/10.1016/j.plaphy.2008.12.001.

Ruales, J. and B.M. Nair. 1992. "Nutritional Quality of the Protein in Quinoa (Chenopodium Quinoa, Willd) Seeds." Plant Foods for Human Nutrition 42 (1): 1-11. https://doi. org/10.1007/BF02196067.

Sikder, S., J. Foulkes, H. West, J. De Silva, O. Gaju, A. Greenland, and P. Howell. 2015. "Evaluation of Photosynthetic Potential of Wheat Genotypes under Drought Condition." Photosynthetica 53 (1): 47-54. https://doi.org/10.1007/s11099-015-0082-9.

Talebnejad, R. and A.R. Sepaskhah. 2015a. "Effect of Deficit Irrigation and Different Saline Groundwater Depths on Yield and Water Productivity of Quinoa." Agricultural Water Management 159: 225-238. https://doi.org/10.1016/j.agwat.2015.06.005.

Talebnejad, R. and A.R. Sepaskhah. 2015b. "Effect of Different Saline Groundwater Depths and Irrigation Water Salinities on Yield and Water Use of Quinoa in Lysimeter." Agricultural Water Management 148: 177-188. https://doi.org/10.1016/j. agwat.2014.10.005.

Talebnejad, R. and A.R. Sepaskhah. 2016. "Modification of Transient State Analytical Model under Different Saline Groundwater Depths, Irrigation Water Salinities and Deficit Irrigation for Quinoa.” International Journal of Plant Production 10 (3): 365-390. https://doi.org/10.22069/ijpp.2016.2903.

Talebnejad, R. and A.R. Sepaskhah. 2018. "Quinoa: A New Crop for Plant Diversification under Water and Salinity Stress Conditions in Iran.” Acta Horticulturae 1190: 101-106. https://doi.org/10.17660/ActaHortic.2018.1190.17.

Talebnejad, R. and A.R. Sepaskhah. 2016. "Physiological Characteristics, Gas Exchange, and Plant Ion Relations of Quinoa to Different Saline Groundwater Depths and Water Salinity." Archives of Agronomy and Soil Science 62 (10): 1347-1367. https://doi.org/ 10.1080/03650340.2016.1144925.

Trognitz, B.R. 2003. "Prospects of Breeding Quinoa for Tolerance to Abiotic Stress." Food Reviews International 19 (1-2): 129-37. https://doi.org/10.1081/FRI-120018879.

Väkeväinen, K., F. Ludena-Urquizo, E. Korkala, A. Lapveteläinen, S. Peräniemi, A. von Wright, and C. Plumed-Ferrer. 2020. "Potential of Quinoa in the Development of Fermented Spoonable Vegan Products." LWT 120: 108912. https://doi.org/10.1016/j. lwt.2019.108912.

Walters, H., L. Carpenter-Boggs, K. Desta, L. Yan, J. Matanguihan, and K. Murphy. 2016. "Effect of Irrigation, Intercrop, and Cultivar on Agronomic and Nutritional Characteristics of Quinoa." Agroecology and Sustainable Food Systems 40 (8): 783-803. https://doi.org/10.1080/21683565.2016.1177805.

Yang, A., S.S. Akhtar, M. Amjad, S. Iqbal, and S.-E. Jacobsen. 2016. "Growth and Physiological Responses of Quinoa to Drought and Temperature Stress." Journal of Agronomy and Crop Science 202 (6): 445-453. https://doi.org/10.1111/jac.12167.

Yarami, N. and A.R. Sepaskhah. 2015. "Physiological Growth and Gas Exchange Response of Saffron (Crocus Sativus L.) to Irrigation Water Salinity, Manure Application and Planting Method." Agricultural Water Management 154: 43-51. https://doi. org/10.1016/j.agwat.2015.03.003. 


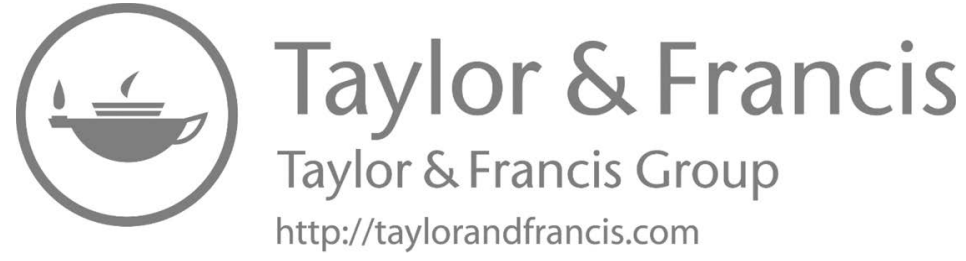

